\title{
A new zygodactylid species indicates the persistence of stem passerines into the early Oligocene in North America
}

\author{
Tobin L. Hieronymus ${ }^{*}$ (D), David A. Waugh ${ }^{1}$ and Julia A. Clarke ${ }^{2}$
}

\begin{abstract}
Background: The lake deposits of the informal Ruby Paper Shale unit, part of the Renova Formation of Montana, have yielded abundant plant fossils that document Late Eocene - Early Oligocene global cooling in western North America. A nearly complete small bird with feather impressions was recovered from this unit in in 1959, but has only been informally mentioned.

Results: Here we describe this fossil and identify it as a new species of Zygodactylus, a stem lineage passerine with a zygodactyl foot. The new taxon shows morphological traits that are convergent on crown Passeriformes, including an elongate hallux, reduced body size, and a comparative shortening of proximal limb elements. The fossil documents the persistence of this lineage into the earliest Oligocene $(\sim 33 \mathrm{Ma})$ in North America. It is the latest occurring North American species of a group that persists in Europe until the Miocene.

Conclusions: Eocene-Oligocene global cooling is known to have significantly remodeled both Palearctic and Nearctic mammal faunas but its impact on related avifaunas has remained poorly understood. The geographic and temporal range expansion provided by the new taxon together with avian other taxa with limited fossil records suggests a similar pattern of retraction in North America followed by Europe.
\end{abstract}

Keywords: Passeriformes, Paleogene, Paleobiogeography, Zygodactylidae

\section{Background}

Zygodactylidae [1] is an extinct clade of small birds that possess a zygodactyl foot, with two pedal digits that are caudally deflected [2-6]. This clade includes the genera Zygodactylus [7], Primozygodactylus [8], Eozygodactylus [9], and Primoscens [10]. Described species are most abundant in Eocene deposits of North America and Europe, although they are also known from the Oligocene and early Miocene of Europe [2, 3, 7, 11]. Indeed, although parts of this clade were first described from the Miocene of Germany and France [7, 11], partial skeletons are only known from the early Oligocene and early Eocene of these same regions and the Eocene of North America. All younger material has been limited to isolated elements. Zygodactylids have been identified as allied with extant songbirds, or stem passerine taxa [3].

\footnotetext{
*Correspondence: thieronymus@neomed.edu

${ }^{1}$ Department of Anatomy and Neurobiology, Northeast Ohio Medical

University, 4209 State Rt 44, Rootstown, OH 44272, USA

Full list of author information is available at the end of the article
}

This recovered relationship and strong support for a passerine/parrot sister taxon relationship [12-14] opened up the possibility that a zygodactyl foot may be ancestral to the entire group [3].

The specimen described here was collected by Herman F. Becker and his field assistant Paul Roper in the last hours of their 1959 field season, while waiting for local rancher Elwyn Metzel to transport their packed camp and specimens to the train station [15]. The focus of Becker's expedition was a floral study of Medicine Lodge and Ruby Basins in southwest Montana for the University of Michigan Museum of Paleontology. The bird fossil was transferred to the care of Glenn Jepsen at the Natural History Museum of Princeton, where it was prepared and put on display [16] but never formally described. The main slab of the specimen was figured in an overview of the Ruby Basin Flora [17] with suggested taxonomic affinity to kinglets or titmice based on the preserved feather crest. Its counterpart was figured in an overview of intermontane basin paleofloras, with 
suggested affinity to sandpipers [18]. In 1985, the specimen was transferred to the Yale Peabody Museum of Natural History. It was illustrated in an examination of fossilized melanosomes and identified as an undescribed Oligocene zygodactylid bird [19] based on a preliminary identification by one of us (Clarke). Here, we assess the phylogenetic affinities of the specimen and its implications for understanding the evolution of the North American Avifauna.

\section{Results}

Systematic paleontology

Aves Linneaus 1758

Parapasseres Mayr 2015

Zygodactylidae Brodkorb 1971

Zygodactylus Ballmann 1969

Zygodactylus ochlurus sp. nov.

\section{Holotype}

YPM VPPU 17053, partially articulated skeleton preserved on main slab and counterpart, including two smaller flakes detached from the counterpart (Fig. 1a-e). Feather impressions surround the skeleton. Most elements are preserved as mouldic impressions and fragments of bone.

\section{Etymology}

From ỏ $\chi \lambda \eta p o ́ s$ (ochlhros), Classical Greek for troublesome, in reference to "Trouble," an orphaned magpie chick that Becker hand-reared in the Fossil Basin camp during his 1959 field season [17].

\section{Type locality and horizon}

Becker locality \#2 in Fossil Basin, Upper Ruby Valley, Madison County [15, 20, 21] (Fig. 1f). Plant fossils from this locality are assigned to the Ruby Basin Flora, lithostratigraphically positioned at the boundary between the Climbing Arrow and Dunbar Creek Members of the Renova Formation [22]. The Dunbar Creek Member is locally capped by the Williams Creek basalt, K-Ar dated to $32.2 \pm 0.4 \mathrm{Ma}$ [23], providing a hard upper bound for the age range. Paleoclimate studies place the Ruby Flora in the earliest Oligocene, ca. $33 \mathrm{Ma}$ [22].

\section{Diagnosis}

Zygodactylus ochlurus shares the combination of a large intermetacarpal process, a dentiform process of the carpometacarpus, a zygodactyl foot, and a greatly elongate tarsometatarsus (longer than or subequal to the humerus) unique to Zygodactylidae [5, 6, 22]. The new taxon is assigned to Zygodactylus based on the distal projection of metacarpal III past metacarpal II, and on the presence of a convexity proximal to the trochlea of metatarsal IV $[2,6]$. The latter character is automorphic for Zygodactylus.

$Z$. ochlurus is differentiated from all other Zygodactylus spp. by (1) anterior projection of cranial cnemial crest greater than anteroposterior width of tarsometatarsus, (2) hallucal digit proximal phalanx longer than pedal digit III proximal phalanx, and (3) diminutive size: most other limb elements are approximately two-thirds the size of corresponding elements in congenerics Zygodactylus grivensis, Z. ignotus, Z. luberonensis, and $Z$. grandei (Table 1) $[2,6,7,11]$. Complete fusion of the synsacral vertebrae in YPM VPPU 17053 are taken here as an indicator of skeletal maturity, and thus adult size, for this specimen.

$Z$. ochlurus is differentiated from Eozygodactylus americanus by (1) shorter lateral sternal trabeculae, (2) femur shorter than humerus, (3) ulna approximately equal to tarsometatarsus in length, (4) presence of a dentiform process on the cranial margin of the carpometacarpus.

Z. ochlurus is differentiated from all Primozygodactylus spp. by (1) a large dorsal supracondylar process of humerus, (2) femur shorter than humerus, (3) metacarpal III longer than metacarpal II, and (4) obturator foramen continuous with ischiopubic fenestra. The new taxon is differentiated from all Primozygodactylus spp. except $P$. danielsi by a relatively elongate proximal phalanx of pedal digit II.

\section{Measurements}

See Table 1.

\section{Description}

Skull

The skull is badly crushed, and is split between main slab (Fig. 1a) and counterpart (Fig. 1b) on a largely parasagittal plane through the right orbit. A short maxillary rostrum relative to skull length is more similar to Eozygodactylus americanus than $Z$. luberonensis $[3,9]$. The bodies and otic processes of both left and right quadrate are visible on the part. Dark-stained matrix in the middle of the skull rests in the right orbit, and obscures the orbital process of the right quadrate. The occipital region remains on the counterpart, including the outline of the left paroccipital process and the middle ear cavity (cavum tympanicum). The outline of the tympanic crest is similar to E. americanus. The mandibular rami are distorted, but appear to display a ventral curvature similar to E. americanus. Crushed remnants of the left palatine are visible rostral to the middle ear cavity on the counterpart.

\section{Vertebral column}

Faint remnants of the cervical column are split between main slab and counterpart, without substantial exposed 


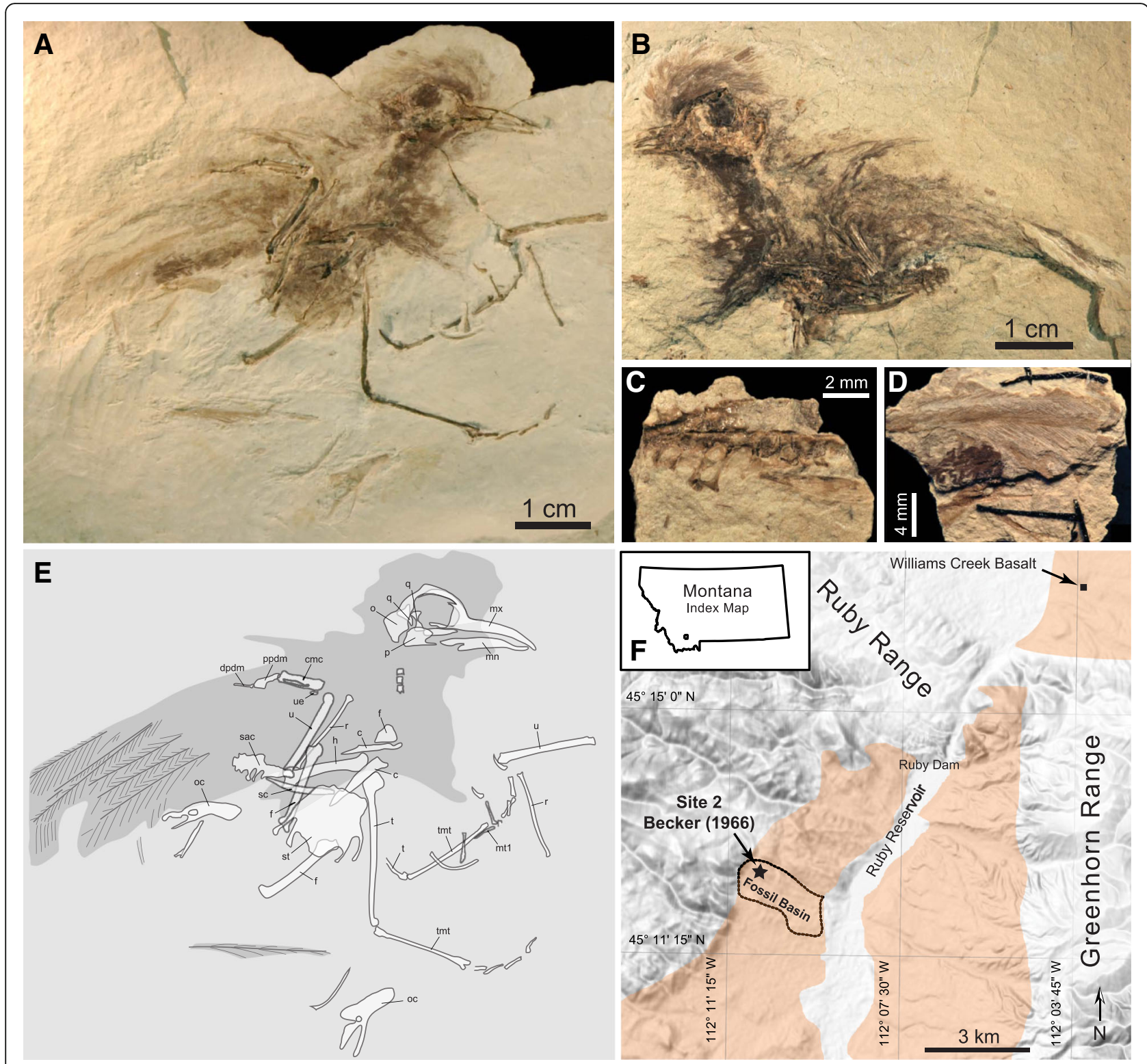

Fig. 1 Holotype specimen of Zygodactylus ochlurus n.sp. (YPM VPPU 17053) with interpretive drawing and geologic context. a Main slab and b counterpart of holotype, with c-d two interstitial fragments. e Line drawing with outlines from part, counterpart, and fragments superimposed. Abbreviations: c, coracoid; $c m c$, carpometacarpus; $d p d m$, distal phalanx digiti majoris; $f$, femur; $h$, humerus; $m n$, mandible; $m t 1$, first $m e t a t a r s a l ; ~ m x$, maxillary rostrum; o, occiput; oc, os coxa; of, omal extremity of furcula; $p$, palatine fragment; ppdm, proximal phalanx digit majoris; $q$, quadrate; $r$, radius; sac, synsacrum; sc, scapula; st, sternum; t, tibiotarsus; tmt, tarsometatarsus; $u$, ulna; ue, ulnare. $\mathbf{f}$ Simplified geologic map of the Upper Ruby River Basin. Inset shows location of the map in Southwestern Montana. Orange overlay indicates surface extent of Renova Fm [61]

surfaces. The body of the sacrum is split between counterpart and first intermediate flake (Fig. 1c). It appears to contain $\sim 11$ vertebrae; nine are visible, but the series is cranially incomplete. Costal processes of the acetabular vertebra are visible on both slabs, while the adjacent body of the sacrum is largely crushed onto the counterpart. Foramina intertransversaria look to be enclosed for at least two of the caudal sacral series.

\section{Pectoral girdle and limb}

The sternal keel is preserved in the main slab. The body of the sternum forms a mouldic impression around the fragmented keel. Spina externa may be fragmentarily preserved alongside the left coracoid on the part, but its outline cannot be determined with any certainty. Right cranial portion of sternum, showing the pila coracoideus, is preserved on the counterpart. There are four sternal incisions caudally, with medial and lateral trabeculae 


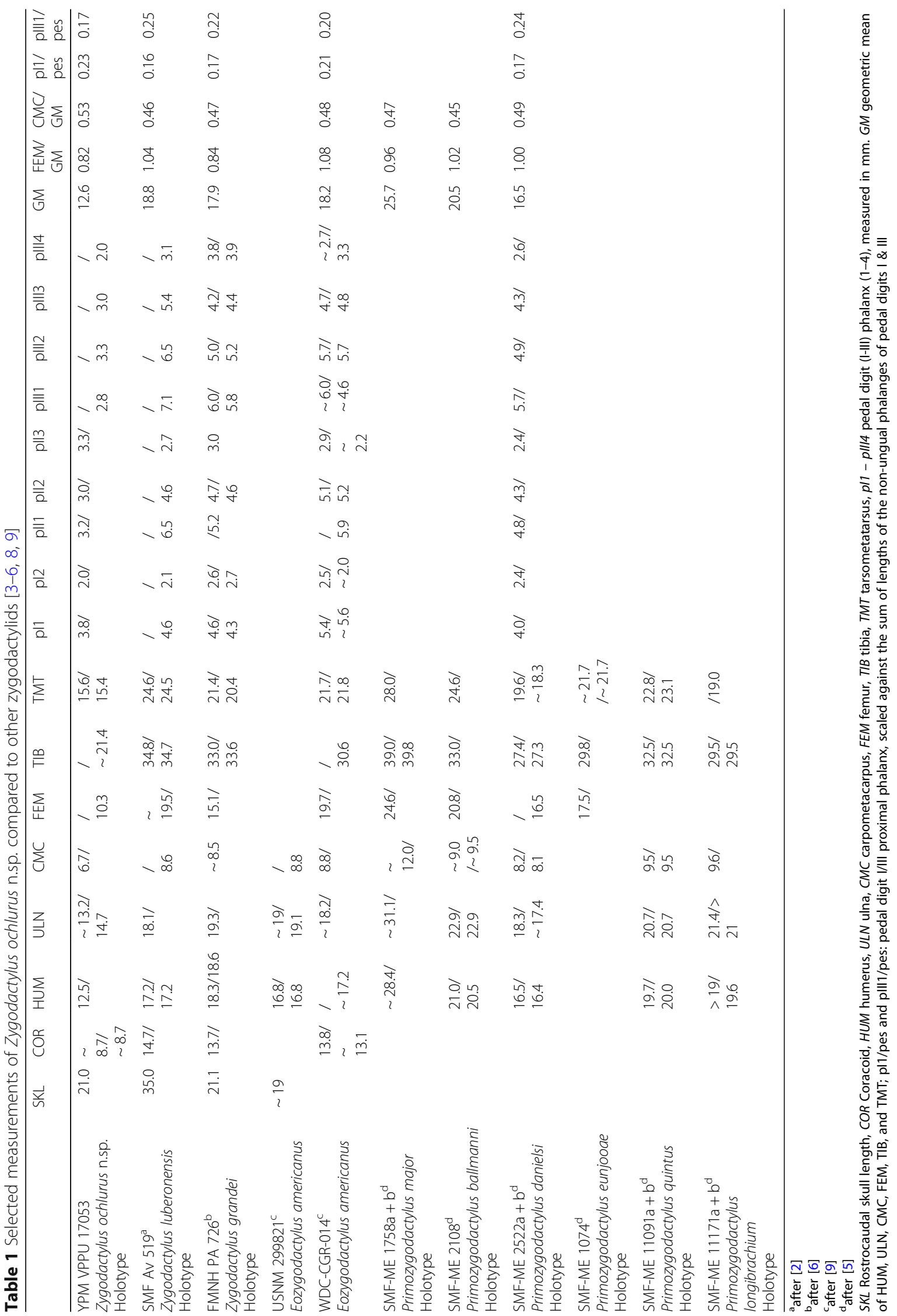


ending in approximately the same plane as the broad caudal midline extremity.

Left scapula is preserved on the counterpart, with matching impression in first intermediate flake. The body of the scapula is less curved than in E. americanus.

An impression of the right coracoid is exposed in dorsal view on the part, missing medial and proximal parts of the flange. The impression shows a weakly developed procoracoid process, as in Z. luberonensis. An incompletely exposed bony remnant adjacent to the right coracoid is tentatively identified as the triangular omal extremity of the furcula. Crushed portions of the left coracoid, without the flange, are preserved in dorsal view on the part. The cranial end projects beneath the impression of the sternum and ends in close proximity to the cranial end of the left scapula.

The left humerus is preserved as an impression of the cranial surface of the shaft with crushed portions of the head on the main slab, and as fragmentary remains on the counterpart. The humerus is stocky and slightly shorter than the ulna. The deltopectoral crest morphology is poorly defined as a faint impression as the element lacks most of its proximodorsal margin. The humeral head is more dorsoventrally narrow than in Z. luberonensis. An impression of a prominent dorsal supracondylar process is apparent proximal to the impression of the dorsal condyle. A narrow flexor process protrudes distal to the ventral condyle, and a portion of this structure is also visible in the first intermediate flake. Humerotricipital and scapulotricipital sulci are present.

The left ulna is preserved as an impression on the main slab, with fragmentary remnants of the body on the counterpart. The distal end and body of the right ulna are preserved on the main slab, with a small fragment of the proximal end preserved on the counterpart. Papillae remigales are not apparent, and the ulnar shaft is straight. The olecranon process is poorly preserved, with a moderate point, similar to $Z$. luberonensis but less pronounced than in extant Passeriformes.

Left radius is preserved as a thin impression on the main slab and as fragments on counterpart, positioned slightly out of articulation with the left ulna. Right radius is preserved as collapsed fragments in the main slab, fully disarticulated from the right ulna. The left ulnare is a poorly-exposed and crushed body on the main slab. The radiale is not visible.

Left carpometacarpus is preserved as a crushed body and impression on the main slab. Metacarpal I is broken off but the area of breakage on metacarpal II suggests it would have been quite short. The ulnocarpal trochlea is preserved as a faint impression and does not appear to be large or significantly projected caudoventrally. Metacarpal III extends distal to metacarpal II. A prominent intermetacarpal process is visible within the narrow intermetacarpal space (Fig. 2b). A dentiform process is
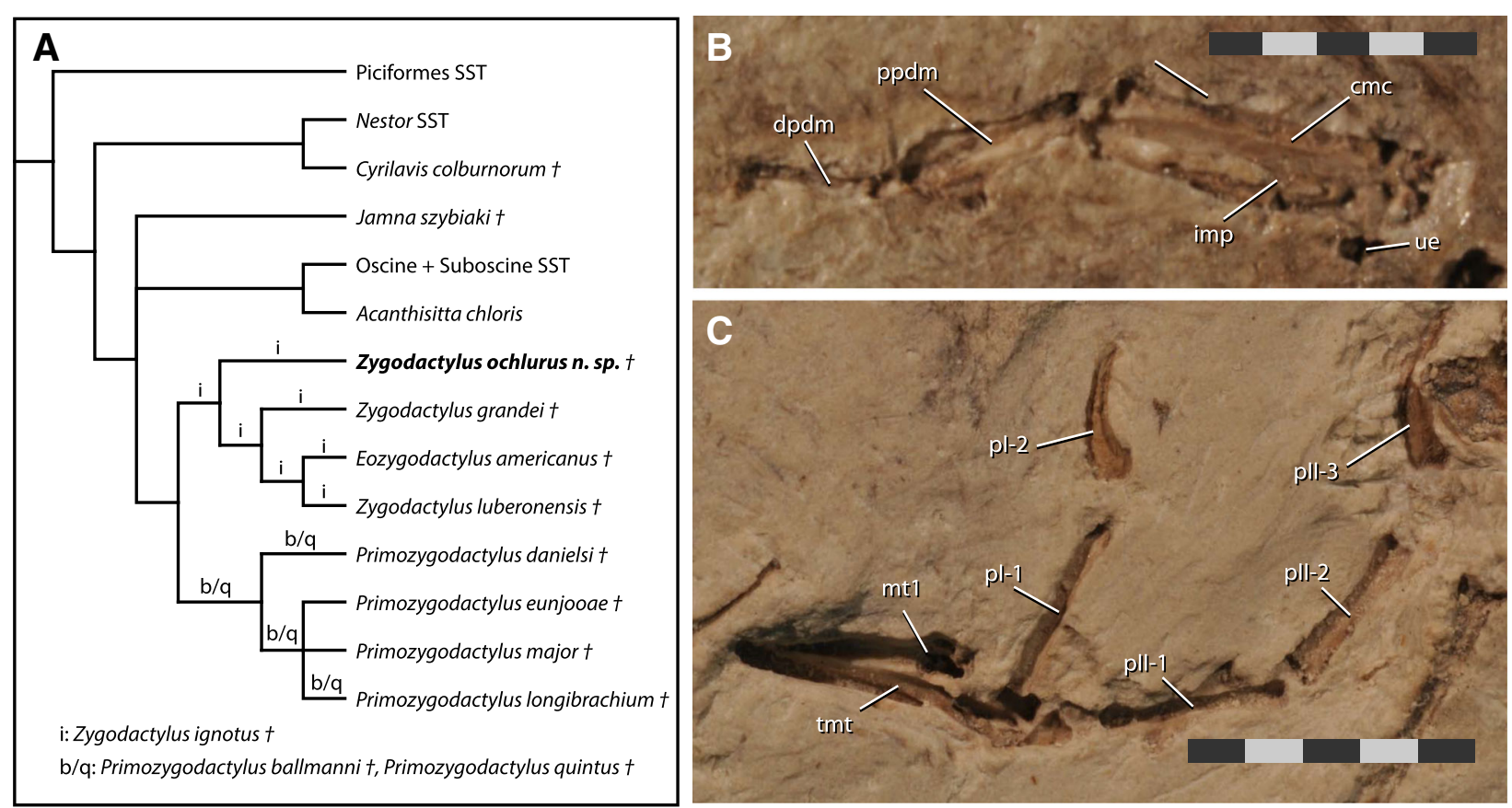

Fig. 2 Phylogenetic context of Zygodactylus ochlurus n.sp. a Reduced consensus of the 30 most parsimonious trees from phylogenetic analysis. Positions of variable taxa are indicated above the branches they occupy in the full tree set. $\mathbf{b}$ Left manus showing intermetacarpal process (imp) c Left pes showing elongate proximal phalanx of digit I ( $\mathrm{pl-1}$ ) 
visible on the cranial margin of major metacarpal. Left major digit is preserved in articulation with carpometacarpus on the main slab. All digits are preserved as impressions in the main slab. Digit III:1 appears to be displaced to lie along side distal II:1. Phalanx II:1 flares distally and is partially overlain by digit II:2. As preserved, the impression of digit II:1 appears to possibly bear a distinct caudodistal processus not dissimilar to that seem in some Galbulae. However, the impression shows a proximodistal furrow that is interpreted as more consistent with an underlying, separate, element such as a carpal or phalanx.

\section{Pelvic girdle and limb}

Left and right pelvic elements are disarticulated from the sacrum and preserved on the main slab, with an additional impression of left pelvic elements on the second intermediate flake (Fig. 1d). The ilium is short and narrow with its preacetabular portion broadly recurved dorsally and longer than its postacetabular portion. The pubis is thin and angles away from the ischium rather than being subparallel to its ventral margin. The obturator foramen is continuous with the ischiopubic fenestra. The right femur is preserved as an impression on main slab, with the distal end passing ventral to sternal impression. Left femur crosses under the impression of the left humerus on the same slab. The femora (Fig. 1e) are elongate and straight. The trochanteric crests are not well projected proximally.

The body and medial cnemial crest of the right tibiotarsus are preserved as an impression with collapsed fragments on the main slab. The large cranial cnemial crest, visible as an impression on the counterpart, is strongly projected cranially and dorsally. Distal end of the left tibiotarsus is visible on the main slab; body may continue beneath the sternum. Both tarsometatarsi are partially crushed. The right tarsometatarsus shows a prominent lateral plantar crest of the hypotarsus, as well as a slight convexity proximal to trochlea IV. Left metatarsal I visible as a separate element alongside the left tarsometatarsus. Pedal phalanges of left digits I, II, and III, right digit III preserved in articulation on the main slab. Digit I:1 is proportionally more elongate in the new taxon than in Z. luberonensis and P. danielsi (Table 1), but comparable to the proportional lengths of digit I:1 in basal Psittacopasseres Avolatavis tenens [24] and Messelastur gratulator [25].

\section{Feathers}

Capital and cervical tract feathers preserved as a darker halo of filamentous structures. Distal primary remiges (IV-IX?) are preserved as impressions on the main slab and second intermediate flake.

\section{Discussion}

\section{Phylogenetic hypotheses}

Analysis with the complete set of 39 equally weighted characters resulted in 30 most parsimonious trees, from implicit enumeration in TNT v1.5. IterPCR identified Zygodactylus ignotus, Primozygodactylus ballmanni, and Primozygodacylus quintus as unstable taxa. A reduced consensus of these 30 trees (Fig. 2a) recovers Zygodactylidae as a monophyletic clade, with further separation of Primozygodactylus and (Zygodactylus + Eozygodactylus) into stable clades recovered in all trees. Z. ochlurus is recovered as the sister taxon of all other Zygodactylus species.

\section{Morphological diversity within Zygodactylidae}

The overall size and limb proportions of $Z$. ochlurus stand out among zygodactylids. When compared using the geometric mean of major limb element lengths (humerus, ulna, carpometacarpus, femur, tibiotarsus, and tarsometatarsus) as a proxy for size, Z. ochlurus is $~ 25 \%$ smaller than any other zygodactylid, and only half the size Primozygodactylus major, the largest member of the family. When individual element lengths are scaled to this body size proxy, $Z$. ochlurus shows a distinctive combination of relatively short femur and relatively long carpometacarpus (Table 1).

Pedal phalanx proportions are another area where $Z$. ochlurus expands the morphological diversity seen in zygodactylids. The elongate proximal phalanx of the hallux that is diagnostic of $Z$. ochlurus is convergent with pedal morphology in oscine and suboscine passeriforms. The proportionally longer pedal digits seen in Z. luberonensis have been proposed to suggest this species was perhaps more terrestrial and suited to more open environments [3]. While the morphology of the new species indicates it is a part of the same zygodactylid subclade, the proportions of the pedal phalanges relative to each other and the tarsometatarsus in $Z$. ochlurus are more similar to those seen in Primozygodactylus spp., and are more consistent with arboreal habit [26]. Taken together, the limb proportions of $Z$. ochlurus suggest greater ecological diversity within the Zygodactylus clade than has previously been appreciated.

\section{Palaeoecological implications}

Paleoclimate interpretations from the Ruby paleoflora show Fossil Basin as a seasonally arid, high-altitude $(\sim 2500 \mathrm{~m})$ temperate scrubland at the beginning of the Oligocene [22]. This setting is a strong contrast from the tropical-subtropical lowland settings in which other Zygodactylus species have been preserved [27], and suggests that zygodactylids were not restricted to relictual tropical habitats following Late Eocene global cooling. Zygodactylid extinction may be 
expected to be explained by more complex factors. If their declining distribution tracked tropical-subtropical environments they may be expected to persist in parts of Africa and Asia [28].

Three major themes of passerine paleobiogeography have emerged from prior analyses. The first is the proposed persistence of the passeriform stem in the separated remnants of Gondwana in the Cenozoic [29]. Second is the vicariance and diversification of suboscines in South America, with subsequent radiation to Africa and Asia [30,31]. Third is the vicariance, diversification, and radiation of oscines from Australia [32]. The geographic distribution of stem passeriform fossils is largely incongruent with the hypothesis of a persistent Gondwanan stem [28, 33]. Z. ochlurus supports a persistent Holarctic distribution of stem passerines from the Paleogene into at least the Early Oligocene of North America as well as Europe incongruent with a stem lineage restricted to the separated remnants of Gondwana.

The Eocene - Oligocene paleogeographic records of birds and mammals in Europe and North America show a consistent pattern. Early Eocene avian and mammalian faunas are similar between Europe and North America $[34,35]$. Late Eocene faunas show a combination of similarity and endemic radiations [34, 36]. By contrast, the Eocene/Oligocene transition is marked by diverging patterns of extinction and faunal turnover. The geologic and paleofloral record in North America suggests a transition to seasonally arid climates $37-35 \mathrm{Ma}$ [37], well in advance of similar transitions in Europe at 34-32 Ma. Clades with considerable species richness in the Eocene disappear from the North American record close to the Eocene/Oligocene boundary, (Coliiformes, mousebirds [38]; Todidae, todies [39]) or are not known after the middle Eocene (e.g., Podargiidae, frogmouths; and Coracii, rollers [40, 41]; Paleognathae [42, 43]) [34].

The disappearances of these taxa with widespread extant distributions have been proposed to track the retraction of key forested environments out of North America [40], similar to proposed patterns in primates [35]. The new species shows at least one subclade of zygodactylids, Zygodactylus, persists at least into the earliest Oligocene of North America. It is also this subclade that is known from the Oligocene and Miocene of Europe $[2,7,11]$.

The European zygodactylid Z. luberonensis was a contemporary of the oldest known European suboscine, both recovered from the Luberon area in France, from deposits dated to $\sim 30 \mathrm{Ma}$ [44], $\sim 6 \mathrm{Ma}$ prior to the closure of the Tethys seaway. Additional passeriform taxa that cannot be confidently assigned within Eupasseres are known from the Rupelian Carpathian Basin of Poland (32-28 Ma) and the Frauenweiler deposits in Germany [45-50]. The earliest European record of oscines (songbirds), which comprise nearly half of the species-level diversity of all extant birds, comes from the late Oligocene deposits of Herrlingen in Germany, and dates to $\sim 24 \mathrm{Ma}$ [51]. The latter date coincides with the uplift of Wallacea in the southwestern Pacific, which is thought to have facilitated the dispersal of oscines from Australia [32]. With Miocene records from Grive-Saint-Alban and Wintershof, zygodactylids persisted in Europe for at least another 6-8 $\mathrm{Ma}$ after oscines arrived, at least until the Miocene climatic optimum $[7,11]$. The oldest definitive crown passeriform currently known from North America is the Miocene Miocitta galbreathi ( 16-13 Ma [52]). An older "passerine" from Florissant [53] is not diagnosable as a member of the crown, and may well represent a zygodactylid.

The early Oligocene may be characterized by Holarctic persistence of an increasingly diverse group of zygodactylids known from distinct environments including inferred arid, higher altitude sites in North America. During this time oscine and suboscine crown Passeres are inferred to be dispersing into these environments [51]. Competitive interactions, documented among extant passeriform groups, have been suggested as factors in the ecological divergence of the crown passeriform radiation [30]. New records are needed to elucidate dynamics and potential drivers of survivorship and extinction during this key interval. With similar body sizes, stem passerines occupy a range of ecological settings in the face of rapidly changing environments in the early days of an late Paleogene icehouse world.

\section{Conclusions}

The morphology of the new taxon is convergent on crown Passeriformes in several respects. The new taxon has a smaller overall size than other zygodactylids. The limb proportions of the new taxon are also convergent on the ranges seen in crown Passeriformes, most notable in the length of proximal phalanx of the hallux.

Oligocene zygodactylids were not confined to relict tropical forests after Late Eocene global cooling. Paleoclimatic reconstructions place $Z$. ochlurus in temperate mountain scrubland, expanding the ecological range of Zygodactylidae.

The new taxon extends the temporal range of North American zygodactylids from the Early Eocene in to the Early Oligocene. This extension supports the idea that passerine stem taxa maintained a persistent presence in the Holarctic, from at least the time of the earliest estimated divergences within the crown $(\sim 52 \mathrm{Ma})$ until well after the proposed dispersal of oscine songbirds into the Holarctic from Australia $(\sim 16 \mathrm{Ma})$. 


\section{Methods}

Taxon and character sampling \& phylogenetic analysis Anatomical features of the Ruby Basin specimen (YPM VPPU 17053) were assessed by comparison to specimens representing the majority of known species in Zygodactylidae: Zygodactylus luberonensis (SMF Av 519); Zygodactylus ignotus (BSP 18164); Zygodactylus grivensis (FSL 151); Zygodactylus grandei (FMNH PA 726); Eozygodactylus americanus (USNM 299821); Primozygodactylus eunjooae (SMF-ME 1074); Primozygodactylus ballmanni (SMF-ME 1768); Primozygodactylus danielsi (SMF-ME 2522); Primozygodactylus longibrachium (SMF-ME 11171); Primozygodactylus major (SMF-ME 2108); and Primozygodactylus quintus (SMF-ME 11091). Thirty-nine discrete morphological characters (Additional file 1: Appendix I) were coded for the new taxon, drawn largely from prior published analyses $[2,4,6,9$, 24, 54-56]. Morphological characters of Zygodactylus luberonensis, Zygodactylus grandei, Zygodactylus ignotus, and Primozygodacylus spp. were evaluated from published sources $[2,3,5,6,8,11]$.

Character states for several outgroup taxa were included from published sources. Extant Passeriformes were represented by two terminal taxa: the basal passeriform Acanthisitta chloris, and a supraspecific terminal (SST) taxon representing basal states for oscine and suboscine passeriforms, using states reported from published studies [6] derived from a composite of Tyrannus tyrannus, Thamnophilus caerulescens, Corvus brachrhynchos, and Menura novaehollandiae. The putative stem passeriform Jamna szybiaki [45] was also included. Psittaciformes were represented by an SST containing Nestor meridionalis and Nestor notabilis [6, 57], as well as a terminal for the fossil stem psittaciform Cyrilavis colburnorum [57]. Piciformes were represented by an SST derived from Dryocopus pileatus, Colaptes auratus, Galbula ruficauda, and Chelidoptera tenebrosa [6].

Phylogenetic analysis used equal weights and a maximum parsimony estimator in TNT $1.5[58,59]$, with a search by implicit enumeration (branch and bound). $Z$. grivensis was excluded due to a large proportions of missing character data. The piciform SST was selected as an outgroup to root the resulting trees. Iterative Reduced Positional Congruence (iterPCR [60]) was used to identify unstable taxa in the set of most parsimonious trees.

\section{Additional file}

Additional file 1: Appendix I Morphological character state descriptions. (DOCX $34 \mathrm{~kb}$ )

\section{Abbreviations}

BSP: Bayerische Staatssammlung für Paläontologie und Historische Geologie, Munchen, Germany; FMNH: Field Museum of Natural History, Chicago, Illinois, USA; FSL: Faculté des Sciences de Lyon, France; SMF: Forschunginstitut
Senckenberg, Frankfurt am Main, Germany; USNM: National Museum of Natural History, Smithsonian Institution, Washington, DC, USA; YPM: Yale Peabody Museum, New Haven, Connecticut, USA

\section{Acknowledgements}

Daniel Brinkman at Yale Peabody Museum graciously provided access to the specimen for study. Beau Bradley granted access to confirm the coordinates of the type locality. Fred Randall Hieronymus, Greg Hieronymus, Mark Hieronymus, Kendra Horn, Randy Lowder provided logistical assistance in the Ruby Valley. Diego Pol, Gerald Mayr, and an anonymous reviewer provided insightful comments that improved the quality of the manuscript.

\section{Funding}

This research was supported by internal funding from NEOMED and NSF IOS $1838746(\mathrm{TH})$; the funding bodies had no role in study design, data collection, analysis and interpretation, or drafting of the manuscript.

Availability of data and materials

The datasets used during the current study are included as appendices.

\section{Authors' contributions}

JC conceived of the study. TH and JC designed the study. TH, DW, and JC collected and analyzed the data. TH drafted the manuscript, JC and DW contributed text, figures, and revisions. All authors read and approved the final version of manuscript.

Ethics approval and consent to participate Not applicable.

Consent for publication

Not applicable.

\section{Competing interests}

The authors declare that they have no competing interests.

\section{Publisher's Note}

Springer Nature remains neutral with regard to jurisdictional claims in published maps and institutional affiliations.

\section{Author details}

${ }^{1}$ Department of Anatomy and Neurobiology, Northeast Ohio Medical University, 4209 State Rt 44, Rootstown, OH 44272, USA. '2University of Texas at Austin, Jackson School of Geosciences, Austin, TX, USA.

Received: 13 June 2018 Accepted: 4 December 2018

Published online: 05 January 2019

References

1. Brodkorb P. Catalogue of fossil birds: part 4 (Columbiformes through Piciformes). Bull Fla State Mus Biol Sci. 1971;15:163-266.

2. Mayr G. Phylogenetic affinities of the enigmatic avian taxon Zygodactylus based on new material from the early Oligocene of France. J Syst Palaeontol. 2008:6(3):333-44.

3. Mayr G, Zelenkov N. New specimens of zygodactylid birds from the middle Eocene of Messel, with description of a new species of Primozygodactylus. Acta Palaeontol Pol. 2009;54(1):15-20.

4. Mayr G. Variations in the hypotarsus morphology of birds and their evolutionary significance. Acta Zool. 2015:196-210.

5. Mayr G. New species of Primozygodactylus from Messel and the ecomorphology and evolutionary significance of early Eocene zygodactylid birds (Aves, Zygodactylidae). Hist Biol. 2017;29(7):875-84.

6. Smith NA, DeBee AM, Clarke JA. Systematics and phylogeny of the Zygodactylidae (Aves, Neognathae) with description of a new species from the early Eocene of Wyoming, USA. Peer J. 2018;6:e4950.

7. Ballmann P. Les oiseaux miocènes de La Grive-saint-Alban (Isère). Geobios. 1969:2:157-204.

8. Mayr G. "Coraciiforme" und" piciforme" Kleinvögel aus dem Mittel-Eozän der Grube Messel (Hessen, Deutschland). Cour Forsch Inst Senckenberg. 1998; 205:1-101.

9. Weidig I. New birds from the lower Eocene Green River formation, North America. Rec Aust Mus. 2010;62(1):29-44. 
10. Harrison C, Walker C. Birds of the British lower Eocene. Tert Res Spec Paper. 1977;3:1-52.

11. Ballmann P. Die vögel aus der altburdigalen Spaltenfüllung von Wintershof (West) bei Eichstätt in Bayern. Zitteliana. 1969;1:5-60.

12. Hackett SJ, Kimball RT, Reddy S, Bowie RCK, Braun EL, Braun MJ, et al. A Phylogenomic study of birds reveals their evolutionary history. Science. 2008;320(5884):1763-8.

13. Jarvis ED, Mirarab S, Aberer AJ, Li B, Houde P, Li C, et al. Phylogenomic analyses data of the avian phylogenomics project. GigaScience. 2015;4(1):4.

14. Prum RO, Berv JS, Dornburg A, Field DJ, Townsend JP, Lemmon EM, et al. A comprehensive phylogeny of birds (Aves) using targeted next-generation DNA sequencing. Nature. 2015;526(7574):569.

15. Becker HF. in litt. Jepsen G; 1971.

16. Becker HF. in litt. Jepsen G; 1961.

17. Becker HF. Paleobotany at the New York botanical garden. Garden Club J. 1960;10(1):10-3.

18. Becker HF. Digging in Montana's evolutionary past. Am For. 1971;77(4):44-59.

19. Vinther J. A guide to the field of palaeo colour. BioEssays. 2015;37(6): 643-56.

20. Dorr JA, Wheeler WH. Cenozoic paleontology, stratigraphy, and reconnaissance geology of the upper Ruby River basin, southwestern Montana: Contrib Paleontol Univ Mich Mus Paleontol. 1964;13:297-339.

21. Becker HF. Additions to the tertiary ruby paper shale flora of southwestern Montana. Bull Torrey Bot Club. 1960:386-96.

22. Lielke K, Manchester S, Meyer H. Reconstructing the environment of the northern Rocky Mountains during the Eocene/Oligocene transition: constraints from the palaeobotany and geology of South-Western Montana, USA. Acta Palaeobotanica. 2012;52(2):317-58.

23. Fritz WJ, Sears J, McDowell R, Wampler J. Cenozoic volcanic rocks of southwestern Montana. Northwest Geol. 2007;36:91-110.

24. Ksepka DT, Clarke JA. A new stem parrot from the Green River formation and the complex evolution of the grasping foot in pan-Psittaciformes. J Vertebr Paleontol. 2012;32(2):395-406.

25. Mayr G. Well-preserved new skeleton of the middle Eocene Messelastur substantiates sister group relationship between Messelasturidae and Halcyornithidae (Aves, ?Pan-Psittaciformes). J Syst Palaeontol. 2011;9(1): 159-71.

26. Rüggeberg T. Zur funktionellen Anatomie der hinteren Extremität einiger mitteleuropäischer Singvogelarten; 1955.

27. Maxwell EE, Alexander S, Bechly G, Eck K, Frey E, Grimm K, et al. The Rauenberg fossil Lagerstätte (Baden-Württemberg, Germany): a window into early Oligocene marine and coastal ecosystems of Central Europe. Palaeogeogr Palaeoclimatol Palaeoecol. 2016;463:238-60.

28. Mayr G. Avian higher level biogeography: southern hemispheric origins or southern hemispheric relicts? J Biogeogr. 2017;44(4):956-8.

29. Claramunt S, Cracraft J. A new time tree reveals earth history's imprint on the evolution of modern birds. Sci Adv. 2015;1(11). https://doi.org/10.1126/ sciadv. 1501005.

30. Selvatti AP, Galvão A, Pereira AG, Pedreira Gonzaga L, CADM R. An African origin of the Eurylaimides (Passeriformes) and the successful diversification of the ground-foraging pittas (Pittidae). Mol Biol Evol. 2016;34(2):483-99.

31. Selvatti AP, Gonzaga LP, Russo CAM. A Paleogene origin for crown passerines and the diversification of the oscines in the New World. Mol Phylogenet Evol. 2015;88:1-15.

32. Moyle RG, Oliveros CH, Andersen MJ, Hosner PA, Benz BW, Manthey JD, et al. Tectonic collision and uplift of Wallacea triggered the global songbird radiation. Nat Commun. 2016;7:12709.

33. Mayr G. Two-phase extinction of "southern hemispheric" birds in the Cenozoic of Europe and the origin of the Neotropic avifauna. Palaeobiodiv Palaeoenviron. 2011;91(4):325-33.

34. Mayr G. Paleogene fossil birds. Berlin: Springer; 2009.

35. Fleagle JG, Gilbert CC. The biogeography of primate evolution: the role of plate tectonics, climate and chance. In: Primate biogeography: Springer; 2006. p. 375-418.

36. Hooker JJ, Collinson ME, Sille NP. Eocene-Oligocene mammalian faunal turnover in the Hampshire Basin, UK: calibration to the global time scale and the major cooling event. J Geol Soc. 2004;161(2):161-72.

37. Pound MJ, Salzmann U. Heterogeneity in global vegetation and terrestrial climate change during the late Eocene to early Oligocene transition. Sci Rep. 2017;7. https://doi.org/10.1038/srep43386.
38. Ksepka DT, Clarke JA. Affinities of Palaeospiza bella and the phylogeny and biogeography of mousebirds (Coliiformes). Auk. 2009;126(2):245-59.

39. Olson S. Oligocene fossils bearing on the origins of the Todidae and the Momotidae (Aves: Coraciiformes). Smithson Contrib Paleobiol. 1976;27:111-9.

40. Clarke JA, Ksepka DT, Smith NA, Norell MA. Combined phylogenetic analysis of a new north American fossil species confirms widespread Eocene distribution for stem rollers (Aves, Coracii). Zool J Linnean Soc. 2009;157(3): 586-611.

41. Nesbitt SJ, Ksepka DT, Clarke JA. Podargiform affinities of the enigmatic Fluvioviridavis platyrhamphus and the early diversification of Strisores ("Caprimulgiformes"+ Apodiformes). PLoS One. 2011;6(11):e26350.

42. Houde P. Ostrich ancestors found in the northern hemisphere suggest new hypothesis of ratite origins. Nature. 1986;324(6097):563-5.

43. Nesbitt SJ, Clarke JA. The anatomy and taxonomy of the exquisitely preserved Green River formation (early Eocene) lithornithids (Aves) and the relationships of Lithornithidae. Bull Am Mus Nat Hist. 2016;406:1-91.

44. Mayr G, Manegold A. A small suboscine-like passeriform bird from the early oligocene of France. Condor. 2006;108(3):717-20.

45. Bochenski ZM, Tomek T, Bujoczek M, Wertz K. A new passerine bird from the early Oligocene of Poland. J Ornithol. 2011;152:1045

46. Bochenski ZM, Tomek T, Swidnicka E. A review of avian remains from the Oligocene of the outer Carpathians and central Paleogene Basin. In: Proceedings of the 8 th international meeting of the society of avian paleontology and evolution, Wien (accepted); 2013.

47. Bochenski ZM, Tomek T, Wertz K, Swidnicka E. The third nearly complete passerine bird from the early Oligocene of Europe. J Ornithol. 2013;154.

48. Bochenski ZM, Tomek T, Swidnicka E. A complete passerine foot from the late Oligocene of Poland. Palaeontol Electron. 2014;17(1):1-7.

49. Mayr G, Manegold A. The oldest European fossil songbird from the early Oligocene of Germany. Naturwissenschaften. 2004;91:173-7.

50. Mayr G, Manegold A. New specimens of the earliest European passeriform bird. Acta Palaeontol Pol. 2006;51(2):315.

51. Manegold A. Passerine diversity in the late Oligocene of Germany: earliest evidence for the sympatric coexistence of suboscines and oscine. Ibis. 2008; 150(2):377-87.

52. Brodkorb P. Neogene fossil jays from the Great Plains. Condor. 1972;74(3): 347-9.

53. Shufeldt RW. Fossil remains of what appears to be a passerine bird from the Florissant shales of Colorado. ProcUnited States National Museum. 1917;53: 453-5.

54. Ashley JF. A study of the structure of the humerus in the Corvidae. Condor. 1941:43(4):184-95.

55. Zelenkov N. The structure and probable mechanism of evolutionary formation of the foot in piciform birds (Aves: Piciformes). Paleontol J. 2007; 41(3):290-7.

56. Manegold A. Earliest fossil record of the Certhioidea (treecreepers and allies) from the early Miocene of Germany. J Ornithol. 2008;149.

57. Ksepka DT, Clarke JA, Grande L. Stem parrots (Aves, Halcyornithidae) from the Green River formation and a combined phylogeny of PanPsittaciformes. J Paleontol. 2012;85(5):835-52.

58. Goloboff PA, Farris J, Nixon K. TNT, a free program for phylogenetic analysis. Cladistics. 2008;24(5):774-86

59. Goloboff PA, Catalano SA. TNT, version 1.5, with a full implementation of phylogenetic morphometrics. Cladistics. 2016;32(3):231-8.

60. Pol D, Escapa $H$. Unstable taxa in cladistic analysis: identification and the assessment of relevant characters. Cladistics. 2009;25:515-27.

61. St. Jean ZC, Teeter DR. Geologic map of the Ruby Dam area, Southwest Montana. Butte: Montana Bureau of Mines and Geology Open-File Report 488,12 p., 2 sheets, scale 1:48,000. 